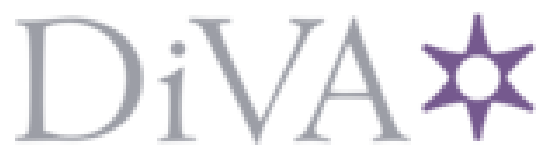

http://www.diva-portal.org

\title{
Postprint
}

This is the accepted version of a paper presented at The Fifth IFIP Conference on Sustainable Internet and ICT for Sustainability Funchal, Portugal - December 6-7, 2017.

Citation for the original published paper:

Björn, H. (2017)

Visualizing Carbon Footprint from School Meals.

In: The Fifth IFIP Conference on Sustainable Internet and ICT for Sustainability,

Funchal, Portugal - December 6-7, 2017

N.B. When citing this work, cite the original published paper.

Permanent link to this version:

http://urn.kb.se/resolve?urn=urn:nbn:se:kth:diva-219812 


\section{Visualizing Carbon Footprint from School Meals}

\author{
Björn Hedin \\ Media Technology and Interaction Design \\ KTH Royal Institute of Technology \\ Stockholm, Sweden \\ bjornh@kth.se
}

\author{
Philip Claesson \\ Media Technology and Interaction Design \\ KTH Royal Institute of Technology \\ Stockholm, Sweden \\ philipcl@kth.se
}

\author{
Patrik Odqvist \\ Media Technology and Interaction Design \\ KTH Royal Institute of Technology \\ Stockholm, Sweden \\ bjornh@kth.se
}

\begin{abstract}
Food is a major contributor of greenhouse gases in the world. Changing what you eat to a less greenhouse gas intensive diet can have a major impact on the greenhouse gas emission. While campaigns and efforts about changing diets directed towards individuals have a potential to reduce total greenhouse gases, efforts directed towards institutional producers of meals have much greater potential to have impact since just a few key players need to be affected. In this paper, we describe a system we have developed for calculating carbon footprint for school meals, making it possible for decisions makers to compare schools with each other, and identify schools with both low footprint (who can serve as good examples) and schools with high footprints (who have the greatest possibility to change). Preliminary results from 10 schools in the Stockholm area are also presented.
\end{abstract}

Keywords- Sustainable HCI; Food; Climate change; Quantified self; Behavior change

\section{INTRODUCTION}

Food accounts for a substantial part of the global emissions of greenhouse gases (GHG). Using consumption based calculations, the Swedish households generate about $30 \%$ of their emissions from food, and to that is added public consumption of food from for example schools [1]. However, different foodstuff varies greatly in GHG emissions, where for example meat and dairy products accounts for about $75 \%$ of the food related GHG emissions but only accounts for 35\% of the total calories consumed [2]. Per kilogram the difference can be even greater, where for example one kilogram of beef causes the same amount of GHG emissions as about 150 kilograms of potatoes [3]. Therefore, there is a great potential to reduce GHG emissions from food by choosing to eat different foodstuff. However, even though plenty of data is publicly available about the GHG emissions of different foodstuff, previous research has shown that units such as "kilograms of carbon dioxide equivalents" or "kilowatt hours" are very difficult to grasp [4,5]. A Quantified Self-solution, where people can measure and reflect upon their own data and compare it to others can be one way to help people grasp complex data. In this paper, we aim for such a solution for schools.

In Sweden, school meals are free and paid by the government, which means there are high possibilities to control how the school meals are composed. The goals of this project were to develop a tool which can calculate and visualize the GHG emissions for schools' purchases of food, and calculate the GHG emissions from a number of schools to see how much the GHG emissions vary and why. In the discussion, we discuss the possible impact on GHG emissions if such a system was used on a larger scale, and a number of potential problems.

\section{BACKGROUND AND RELATED RESEARCH}

Trying to change other's behaviors is both controversial and difficult, and changing behavior of a large portion of the population is very difficult. An approach that could give greater effect is to try to influence people whose decisions affect a greater number of other people. One such group of people is people who decide what meals to serve in public settings, such as schools. Expressed in behavior change terms the target behavior is that people in charge of buying food for schools should choose food with lesser GHG emissions, but in order to do that they would be helped by knowing 1) the current level of GHG emissions (a baseline), 2) how much does each ingredient contribute to the total GHG emissions, and 3) how does this compare with other comparable schools. We have designed a digital system that provides this information. The design has used the COM-B framework for behavior change interventions [6] and tried to address "reflective motivation" (knowledge about that choosing different foodstuff is possible and has a large effect, combined with your school's baseline), and "psychological capability" (knowledge about the effect changing specific foodstuff would have). We use the intervention functions "education" (educating about the GHG effects from your school's meals) and "modeling" (providing role models of schools with high quality food with low GHG impact). We use the behavior change techniques "Selfmonitoring of outcomes of behavior", "Feedback on outcomes of behavior", "information about social and environmental consequences" and "social comparison" from the Behavior Change Taxonomy [7].

\section{METHOD}

The prototype developed for calculating and visualizing GHG emissions from schools are presented in the next section. This tool was then used on data supplied from the municipality of Stockholm, who provided us with data about the foodstuff bought for 17 different schools run by the municipality. The data was scanned and all schools with total carbon dioxide equivalents $\left(\mathrm{CO}_{2} \mathrm{e}\right)$ emissions less than 10 tons were removed since the data was either incomplete or so limited that individual purchases could cause very high changes in total

This research was funded by the Swedish Energy Agency. 
GHG emissions. This left 9 schools which were analyzed further using the output of the prototype.

\section{THE PROTOTYPE}

For calculating the greenhouse gas emissions from the schools, we developed a prototype using a number of components.

The data about the foodstuff each school bought was collected from a procurement system for foodstuff used by the municipality of Stockholm for ordering food for the schools, "Hantera Livs". The system contains all entries of all foodstuff bought during specified periods. Relevant data for our purposes was

- Article name, for example "Onions, sliced"

- Weight per unit, for example " 2 x $2.5 \mathrm{~kg}$ ”

- Main group, for example "Vegetables"

- Sub group, for example "Onion, yellow"

- Total number of units, for example " 150 ”

- School name, for example "Globala gymnasiet"

This data was then fed to a word matching algorithm, which matched the sub group to the categories of food in a database for food and $\mathrm{CO}_{2}$ developed earlier in the project, LCAFDB [8]. This database contains both $\mathrm{CO}_{2}$ data for foodstuff, but also synonyms so for example both "sliced chicken" and "chicken nuggets" are matched to the category "chicken". When a match was found, the weight per unit was multiplied by the total number of units for a total weight, which in turn was multiplied by the average $\mathrm{CO}_{2} \mathrm{e}$ footprint per weight for that specific foodstuff, as returned by a call to the API for LCAFDB. In cases where no match was found, the main group was used instead which gave a less precise but still useable result.

The result was then presented graphically to the user of the system. Figure 1 shows the $\mathrm{CO}_{2} \mathrm{e}$ emissions per kilogram of foodstuff bought for each school for a period of three months. As seen in the diagram the result varies greatly by different schools. At the top of the chart the total amount of $\mathrm{CO}_{2} \mathrm{e}$ generated by all schools are listed, in this case almost 800 tons.

Clicking on a specific bar/school brings up the details for that specific school. The values for one school is shown in Figure 2. At the top of the page the total $\mathrm{CO}_{2}$ emissions from the school is listed. The left column shows the which percentage of the total emission can be derived from which foodstuff. For example, in this case beef ("nötkött", the light blue bar at the bottom of the diagram) accounts for about $28 \%$ of the total emissions. The right column shows the same foodstuffs using the same color, so we can there see that beef is only about $3 \%$ of the total weight of all the foodstuff bought.

\section{RESULTS}

Using the average GHG emissions for each school we could identify two different groups of schools which were statistically different. The low-emission group had an average
GHG footprint of $1.60 \mathrm{~kg} \mathrm{CO} \mathrm{CO}_{2} \mathrm{ekg}$ and the high-emission group had an average GHG footprint of $3.43 \mathrm{~kg} \mathrm{CO} \mathrm{CO}_{2} \mathrm{e} / \mathrm{kg}$.

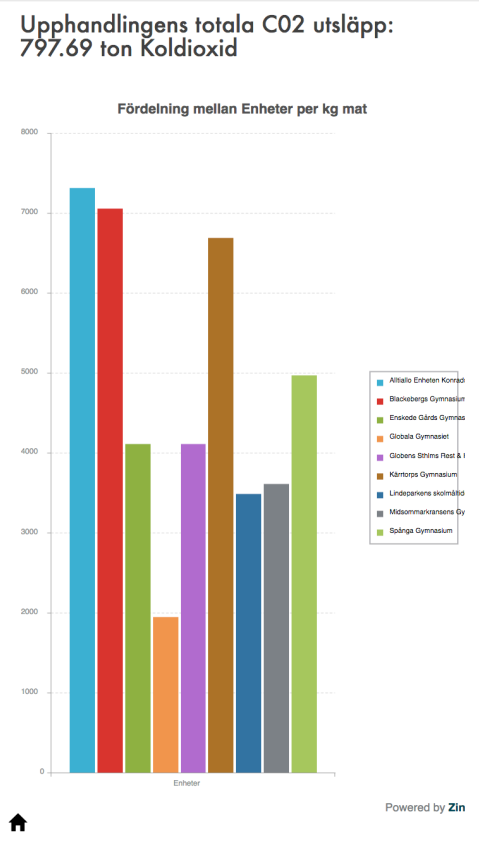

Fig. 1. $\mathrm{CO}_{2} \mathrm{e}$ emissions per kilogram of food for the nine sample schools.

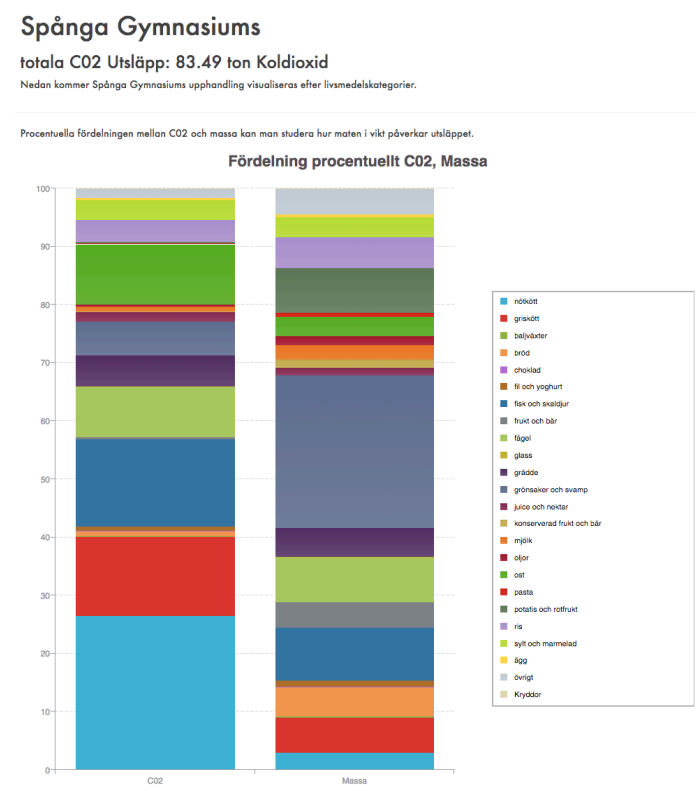

Fig. 2. Distribution of $\mathrm{CO}_{2} \mathrm{e}$ emissions per foodstuff, and total weight per foodstuff for one school.

Looking further at these two groups, the major difference was that the low-emission schools served virtually no beef ( $0.05 \%$ of the total weight), whereas in the high-emission schools beef accounted for between $23.3 \%$ and $31.6 \%$ of the total emissions from the schools, even though the weight of the beef was only between $2.7 \%$ and $4.3 \%$ of the total weight of the food bought. The amount of pork, fish and poultry used in the high-emission schools was also significantly higher. The 
low-emission schools on the other hand had higher use of protein based on soy, legumes or mushrooms which have much lower GHG emissions than meat-based sources of protein, and they also had a higher use of vegetables.

The difference between high-emission schools and lowemission schools was $1.83 \mathrm{~kg} \mathrm{CO} \mathrm{CO}_{2} \mathrm{e} / \mathrm{kg}$ food, or expressed as percentages the low-emission schools emitted only about $47 \%$ of the GHG emissions per kilo compared to the high-emission schools. In our sample of schools, $71 \%$ of the pupils were in high-emission schools. Extrapolating this to a national level, if the high-emission schools changed their meals to the lowemission profiles, the total emissions for 1.3 million Swedish pupils (from a population of 10 million inhabitants) would mean reducing the national GHG emissions by 79.000 tons.

\section{DISCUSSION}

This project has demonstrated how GHG emissions from food used in schools can be visualized, and shown that for many schools most GHG emissions can be traced to a few specific foodstuffs. It has also shown that some schools have much lower GHG emissions than others, where the reason is that they have chosen less GHG intensive foodstuff. Especially the possibility to reduce beef consumption was shown to have a significant effect. Previous research has shown that reducing the consumption of beef and other ruminants is considered "the only dietary change that with high certainty is unavoidable if the EU climate targets are to be met" [3]. While the result that different foodstuff contributed differently to GHG emissions were expected, the significant differences between schools were unexpected. Knowledge about such differences can serve as a basis for change, where schools with higher GHG emissions can be inspired by those with lower emissions who can serve as role models.

However, putting too much faith in a tool like this without a more detailed analysis could be misleading.

One example is that in our model, the GHG emissions are related to weight of the food, not nutritional values. Looking blindly at these values could lead to choices that would be climate friendly but would lead to malnutrition. For example, feta cheese has a very high carbon footprint of about $8 \mathrm{~kg}$ $\mathrm{CO}_{2} \mathrm{e} / \mathrm{kg}$ whereas carrots have very low footprint of about 0.1 $\mathrm{kg} \mathrm{CO} 2 \mathrm{e} / \mathrm{kg}$. A seemingly simple solution would be to replace feta cheese in a salad buffet with carrots and thereby lowering the carbon footprint by almost $99 \%$. However, the number of calories for feta cheese is about $3000 \mathrm{kcal} / \mathrm{kg}$ whereas carrots have only $440 \mathrm{kcal} / \mathrm{kg}$. If the calculations in our prototype was based on calories instead of kilograms, the reduction would instead be $91 \%$.

The calculations must also be complemented with data about whether the students actually like and eat the food or not. A school serving only mashed potatoes would get a very low carbon footprint calculated as $\mathrm{kg} \mathrm{CO}_{2} \mathrm{e} / \mathrm{kg}$, and even lower based on total $\mathrm{CO}_{2} \mathrm{e}$ emissions since most students would likely not eat school meals after a while, but such "gaming" of the calculations would not be desirable by anyone.

Another problem could be incomplete data. In our data, the purchases are gathered from a central procurement system, but in other schools or countries the purchases might be scattered among several different systems, and not as structured as in this case.

\section{FUTURE WORK}

This has been a pilot study where the actual effect in terms of behavior change has not been studied. We would like to test this system in full, and provide relevant people in charge of food purchases in school with the tool to see if any quantitative change can be measured. We would also like to do a more qualitative analysis where we can collect more data about how these key people reason when they decide what to serve as school meals.

\section{REFERENCES}

[1] Naturvårdsverket, "Konsumtionsbaserade utsläpp av växthusgaser per område - Naturvårdsverket." [Online]. Available: http://www.naturvardsverket.se/Sa-mar-miljon/Statistik-A-

O/Vaxthusgaser-konsumtionsbaserade-utslapp-per-omrade/. [Accessed: 29-Sep-2017].

[2] J. Larsson, "Hållbara konsumtionsmönster : Analyser av maten, flyget och den totala konsumtionens klimatpåverkan idag och 2050," Naturvårdsverket, 2015.

[3] D. Bryngelsson, S. Wirsenius, F. Hedenus, and U. Sonesson, "How can the EU climate targets be met? A combined analysis of technological and demand-side changes in food and agriculture," Food Policy, vol. 59, pp. 152-164, Feb. 2016.

[4] J. L. Zapico, M. Turpeinen, and N. Brandt, "Climate persuasive services: changing behavior towards low-carbon lifestyles," in Proceedings of the 4th International Conference on Persuasive Technology, 2009, p. 14:1--14:8.

[5] B. Hedin and J. Zapico, "Kilowh.at -- Increasing Energy Awareness Using an Interactive Energy Comparison Tool," in Persuasive Technology: Development and Implementation of Personalized Technologies to Change Attitudes and Behaviors: 12th International Conference, PERSUASIVE 2017, Amsterdam, The Netherlands, April 4--6, 2017, Proceedings, P. W. de Vries, H. Oinas-Kukkonen, L. Siemons, N. Beerlage-de Jong, and L. van Gemert-Pijnen, Eds. Cham: Springer International Publishing, 2017, pp. 175-185.

[6] Michie, S., van Stralen, M.M., West, R.: The behaviour change wheel: A new method for characterising and designing behaviour change interventions. Implement. Sci. 6, 42 (2011).C. Abraham and S. Michie, "A taxonomy of behavior change techniques used in interventions.," Heal. Psychol., vol. 27, no. 3, p. 379, 2008.

[7] C. Abraham and S. Michie, "A taxonomy of behavior change techniques used in interventions.," Heal. Psychol., vol. 27, no. 3, p. 379, 2008.

[8] B. Hedin, "LCAFDB - A Crowdsourced Life Cycle Assessment Database for Food". Submitted to "5:th IFIP Conference on Sustainable Internet and ICT for Sustainability", Funchal, Portugal - December 6-7, 2017 